\title{
Microscopic, histochemical and preliminary phytochemical characterization of leaves of Trema micrantha (L.) Blume
}

Cledson dos Santos Magalhães ${ }^{1}$, Rafaela Damasceno Sá ${ }^{1}$, Solma Lúcia Souto Maior de Araújo Baltar ${ }^{2}$ \& Karina Perrelli Randau ${ }^{1}$

1 Departamento de Ciências Farmacêuticas, Universidade Federal de Pernambuco, 50740-321, Recife, Pernambuco, Brazil. 2 Universidade Federal de Alagoas, 57309-005, Arapiraca, Alagoas, Brazil.

\section{Correspondence \\ K.P. Randau}

E-mail: krandau@hotmail.com

Received: 22 November 2020

Accepted: 15 April 2021

Published on-line: 30 May 2021

\section{Resumen}

Caracterización microscópica, histoquímica y fitoquímica preilminar de las hojas de Trema micrantha (L.) Blume

Para enriquecer el conocimiento sobre Trema micrantha (L.) Blume, esta investigación tuvo como objetivo realizar la caracterización anatómica, histoquímica y fitoquímica de las hojas de la especie. Se realizaron cortes transversales del pecíolo y limbo, así como cortes paradérmicos del limbo, analizados en microscopía óptica y polarizada. Se utilizaron diferentes reactivos para el análisis histoquímico. Se han descrito estructuras anatómicas que proporcionan un diagnóstico detallado de las especies estudiadas. La histoquímica mostró la presencia de metabolitos esenciales (flavonoides, taninos, entre otros) para la especie y mediante análisis SEM-EDS se confirmó que los cristales están compuestos por oxalato de calcio. El análisis fitoquímico permitió la identificación de mono y sesquiterpenos, triterpenos y esteroides, entre otros. El estudio proporcionó datos sin precedentes sobre la especie, ampliando la información científica de T. micrantha.

Palabras clave: Cannabaceae; Microscopía; Farmacobotánica.

\begin{abstract}
In order to enrich the knowledge about Trema micrantha (L.) Blume, this research aims to perform the anatomical, histochemical and phytochemical characterization of the leaves of this species. Cross sections of the petiole and limbus were made, as well as paradermic sections of the limbus, analyzed in optical and polarized microscopy. Different reagents were used for histochemical analysis. Anatomical structures have been described and provide a detailed diagnosis of the species studied. Histochemistry showed the presence of essential metabolites (flavonoids, tannins, among others) for the species and through SEM-EDS analysis it was confirmed that the crystals are composed of calcium oxalate. Phytochemical analysis allowed the identification of mono and sesquiterpenes, triterpenes and steroids, among others. The study provided unprecedented data on the species, expanding the scientific information of T. micrantha.
\end{abstract}

Key words: Cannabaceae; Microscopy; Pharmacobotany. 


\section{Introduction}

Trema micrantha (L.) Blume, popularly known as candiúba, candiúva, crindiúva, grandiúva, paupólvora, pau-de-bugre, among others, is a tree of the family Cannabaceae (Moressi et al. 2014).

The description of this family had been quite questionable, since traditionally their genera were included in Urticaceae or Moraceae, or it was confused with the complex Ulmaceae-CeltidaceaeCannabaceae (Martins \& Pirani 2009). However, due to the accumulation of studies in phylogeny (Yang et al. 2013), the previously used Cannabaceae classification was expanded, and the genera Celtis L. and Trema Lour. were included in the family. Before that, these genera belonged to the Ulmaceae family (Martins \& Pirani 2009). Thus, the family Cannabaceae presents 10 genera and estimates include about 110 species (APG IV 2016). In Brazil, only the genera Celtis and Trema occur, with five and one species, respectively (Machado \& Silva 2020).

Native from Brazil, T. micrantha can reach 1.5-10 $\mathrm{m}$ in height (Viana \& Gil 2018), inhabiting different vegetation communities (seasonal forests, riparian forests, cerrado and carrasco, as well as in xerophytic vegetation, such as Caatinga) (Martins \& Pirani 2009, Machado \& Silva 2020).

In Brazil, T. micrantha is commonly used in the recovery of degraded or burned soils, as well as in traditional medicine (Lorenzi 2000, Moressi et al. 2014, Oliveira et al. 2018). Its leaves are traditionally used in teas indicated for the treatment of syphilis, rheumatism (Lorenzi 2000), diabetes (Schoenfelder et al. 2006) and to combat poisoning from snakebite (Thomas 2001). Extracts from T. micrantha leaves showed analgesic, antiinflammatory (Barbera et al. 1996) and hypoglycemic activities in animals (Schoenfelder et al. 2006).

Taken all this into consideration, T. micrantha has great potential for medicinal exploitation. However, there is still few information in the literature on its anatomical characteristics and its chemical compounds. A recent research has focused primarily on histolocalization tests on $T$. micrantha trichomes (Nascimento 2017). Therefore, this study aimed to expand the scientific information on the species, through the anatomical, histochemical and phytochemical characterization of its leaves. Thus, the data obtained assist in the correct identification of T. micrantha and on the exact localisation of its compounds.

\section{Materials and methods}

Expanded leaves of adult specimens of T. micrantha, located between the third and fifth node, were collected in the city of Janga, in the community of Tururu, Pernambuco, Brazil. Voucher specimen $\mathrm{n}^{\circ}$ 88149 was deposited in the Herbarium Dárdano de Andrade Lima, of the Instituto Agronômico de Pernambuco (IPA).

For the anatomical characterization, the material was fixed in FAA50 (formaldehyde, acetic acid and ethyl alcohol 50\%, 1:1:18 v/v) (Johansen 1940). Cross-sections of petiole and leaf blade were obtained by the classical sectioning method using a common razor blade. For the leaf blade, paradermic sections were also performed on the adaxial and abaxial faces. Subsequently, the sections were submitted to the treatment with a solution of sodium hypochlorite $(50 \%)$ for clarification (Kraus \& Arduin 1997). After washing in distilled water, the cross-sections were stained according to the technique described by Bukatsch (Bukatsch 1972), with safranin and Astra blue; the paradermic sections were stained with methylene blue (Krauter 1985). Thereafter, all sections were mounted on semipermanent slides, following usual procedures in plant anatomy (Johansen 1940, Krauter 1985). A light and polarization microscope (Leica DM750M), coupled with a digital camera (Leica ICC50W), were used to analyse the slides, through which were obtained images processed by software (LAS EZ).

Histochemical tests were performed in crosssections of fresh leaf blades, obtained by the same method used for anatomical characterization. The following reagents were used to indicate the presence of the metabolites: potassium dichromate (10\%) for phenolic compounds (Johansen 1940); Dragendorff for alkaloids (Sass 1951), vanillin chloridric for tannins (Yoder \& Mahlberg 1976); Sudan III for lipophilic compounds (Mace \& Howell 1974); antimony trichloride for triterpenes and steroids (Mace et al. 1974); Nadi reagent for essential oils (David \& Carde 1964); Lugol for starch (Johansen 1940); phloroglucinol for lignin (Johansen 1940) and hydrochloric acid (10\%) to establish the nature of the crystals (Jensen 1962). Controls were performed in parallel to the histochemical tests and semipermanent slides were prepared containing cross-sections (Johansen 1940, Mace \& Howell 1974). The analysis of the 
slides was conducted on images, using Toup View Image software, obtained by a digital camera coupled to a light microscope (Alltion).

For analysis of the elemental composition of the crystals, cross-sections of fresh leaf blades were fixed in Karnovsky solution for at least 2 hours. Subsequently, samples were washed three times with $1 \mathrm{M}$ sodium buffer, post-fixed with $0.5 \%$ osmium tetroxide and washed again with $1 \mathrm{M}$ cacodylate buffer and with distilled water. After dehydration in ethanol series, the material was submitted to critical point drying (Bal-Tec CPD 030), mounted on stubbs and sputter-coated with gold (Haddad et al. 1998). Chemical microanalyses by Energy Dispersive Spectroscopy (EDS) were performed with an X-ray detector coupled to a scanning electron microscope (TESCAN - Mira 3 SEM) at the Laboratório de Microscopia Eletrônica of the Departamento de Física of the Universidade Federal de Pernambuco (UFPE).

The phytochemical profile was performed from $10 \%$ methanolic extracts of leaf blades of $T$. micrantha obtained by decoction. Silica gel plates were used (Macherey-Nagel) to Thin Layer Chromatography (TLC), employing different eluting systems and appropriate revelators, following a protocol developed in the Laboratório de Farmacognosia of the Departamento de Ciências Farmacêuticas-UFPE, supported in studies of Harborne (1998) and Wagner and Bladt (2001), with modifications (Randau et al. 2004). The investigated metabolites were: phenylpropanoglycosides flavonoids, cinnamic acid derivatives, coumarins, condensed tannins, hydrolysable tannins, monoterpenes, sesquiterpenes, triterpenes, steroids, anthraquinones, saponins, alkaloids and reducing sugars.

\section{Results}

The T. micrantha petiole, in cross-section, presents a concave-convex shape, with two proeminences on the adaxial side (Fig. 1A). The epidermis is uniseriate and covered by a slightly thick cuticle layer (Fig. 1A). Two types of trichomes are observed: non-glandular conical with cystolites at the base and glandular filiform multicellular uniseriate (Fig. 1B). Adjacent to the epidermis, the angular collenchyma, with about two to five layers is found (Fig. 1A). In the central parenchyma there is a closed collateral vascular bundle, arranged in an open arch shape turned facing the adaxial face (Fig. 1A). Druses are found in the parenchyma and phloem (Figs. 1C and 1D).

The leaf blade, in frontal view, presents cells of straight contour in the adaxial face (Fig. 2A) and of slightly sinuous contour in the abaxial face (Fig. 2B). It is classified as hypostomatic, with anomocytic stomata (Fig. 2B). Non-glandular and glandular trichomes are observed in both faces (Figs. 2A and 2B). They are similar to those found in the petiole.

In cross-section, the midrib shows a plan-convex contour, presenting uniseriate epidermis, covered by a slightly thick cuticle (Fig. 2C). Subepidermal angular collenchyma has about four layers (Fig. 2D). As in the petiole, the vascular bundle is collateral, closed and arranged in the shape of an arch (Fig. 2D). Druses are found in the parenchyma and phloem (Figs. 2E and 2F).

The mesophyll is dorsiventral, with palisade parenchyma composed of one to two layers of cells and spongy parenchyma with small intercellular spaces (Fig. 2G). the presence of cystoliths is observed at the base of the non-glandular trichomes, both on the adaxial and abaxial faces (Fig. 2G). Druses are found throughout the mesophyll (Figs. 2F and 2G).

The figure 3 presents the results of the histochemistry, showing in cross-section the leaf blade without addition of no reagent in figure $3 \mathrm{~A}$ and 3B. Phenolic compounds were found in the palisade parenchyma (Fig. 3C) and alkaloids in the spongy parenchyma (Fig. 3D). Lipophilic compounds were observed in the cuticle and epidermis (Fig. 3E). Possibly the lipophilic compounds are essential oils, which have also been found in the epidermis (Fig. 3F). The lignin was evidenced in the xylem (Fig. 3G). The test with hydrochloric acid $(10 \%)$ demonstrated that the druses are of calcium oxalate (Fig. 3H and 3I). Tests for starch, tannins, triterpenes and steroids were negative. Through SEM-EDS analysis it was also verified that the crystals are of calcium oxalate (Fig. 4).

Table 1 shows the results obtained after phytochemical prospection of leaf extracts of $T$. micrantha.

\section{Discussion}

The types of trichomes found in the petiole and leaf blade of $T$. micrantha have been previously described by Sweitzer (1971) and Adamski \& 


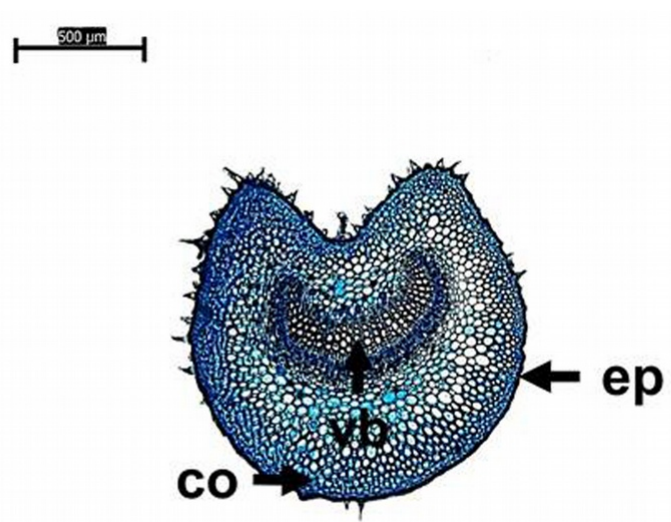

A

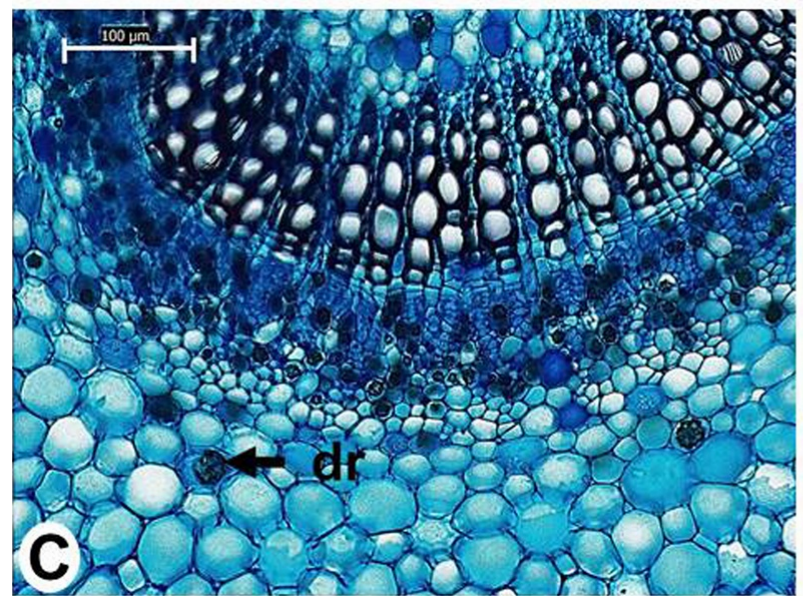

Figura 1. Secciones transversales del pecíolo de Trema micrantha (L.) Blume. A: vista general; B: detalle de tricomas; C, D: detalle de haz vascular y drusas en microscopía de luz y polarizada. co: colénquima; dr: drusa; ep: epidermis; gt: tricoma glandular; ngt: tricoma no glandular; vb: haz vascular.

Figure 1. Cross-sections of the petiole of Trema micrantha (L.) Blume. A: general view; B: detail of trichomes; C, D: detail of vascular bundle and druses in light and polarized microscopy. co: collenchyma; dr: druse; ep: epidermis; gt: glandular trichome; ngt: non-glandular trichome; vb: vascular bundle.
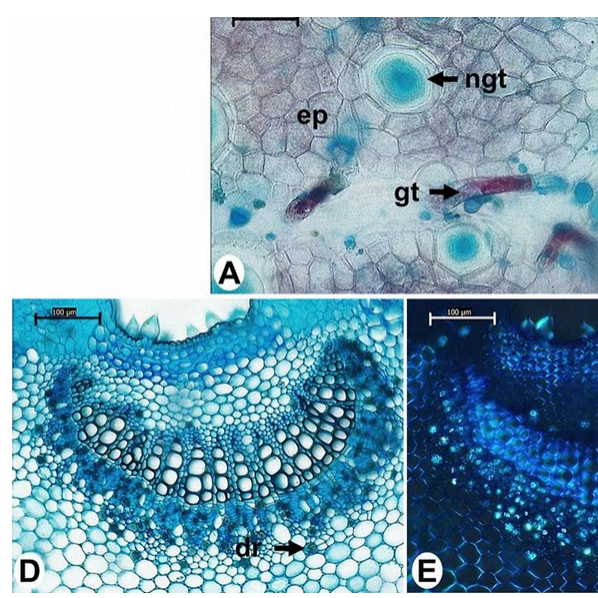

Figura 2. Vista frontal y cortes transversales del limbo de Trema micrantha (L.) Blume. A: cara adaxial; B: cara abaxial; C: vista general de la sección transversal; D, E: detalle de haz vascular y drusas; F, G: detalle de drusas en mesófilo. A, B, C, D, F: microscopía óptica; E, G: microscopía polarizada. co: colénquima; cys: cistolito; dr: drusa; ep: epidermis; gt: tricoma glandular; ngt: tricoma no glandular; pp: parénquima en empalizada; sp: parénquima esponjoso; st: estomas; vb: haz vascular.

Figure 2. Frontal view and cross-sections of the leaf blade of Trema micrantha (L.) Blume. A: adaxial face; B: abaxial face; C: general view of cross-section; D, E: detail of vascular bundle and druses; F, G: detail of druses in mesophyll. A, B, C, D, F: light microscopy; E, G: polarized microscopy. co: collenchyma; cys: cystolith; dr: druse; ep: epidermis; gt: glandular trichome; ngt: non-glandular trichome; pp: palisade parenchyma; sp: spongy parenchyma; st: stomata; vb: vascular bundle. 


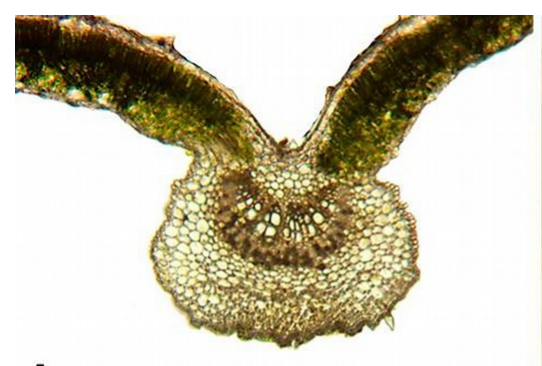

A
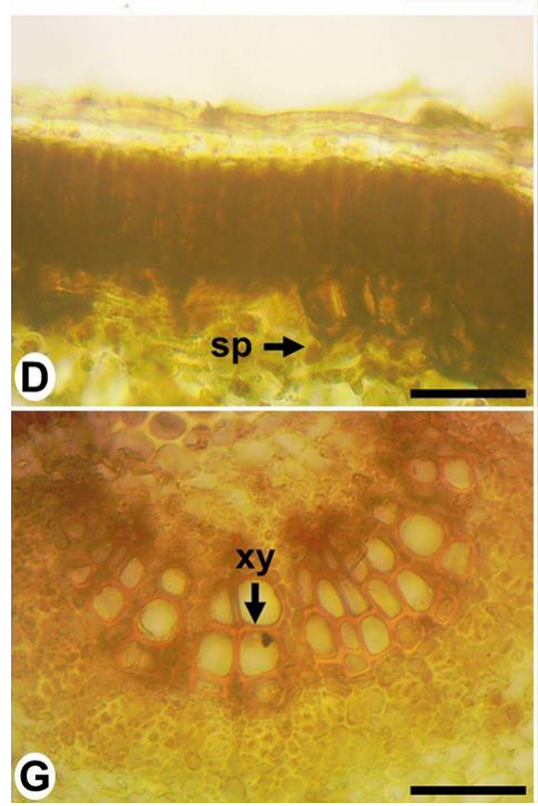

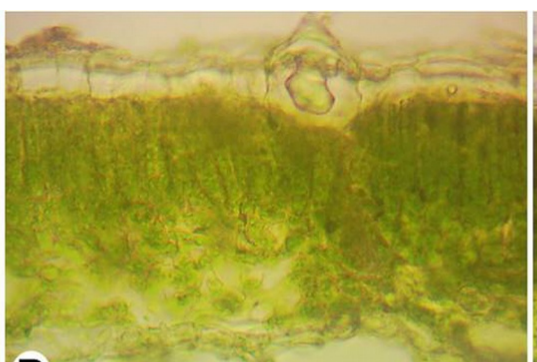

B
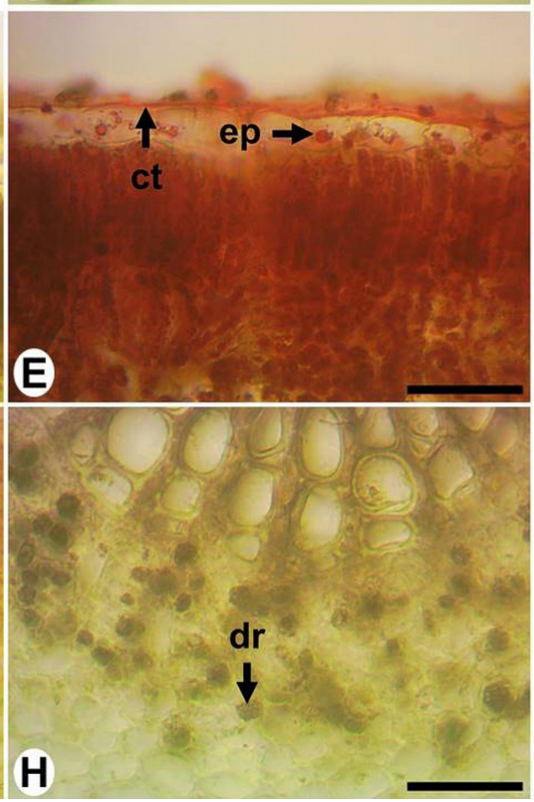

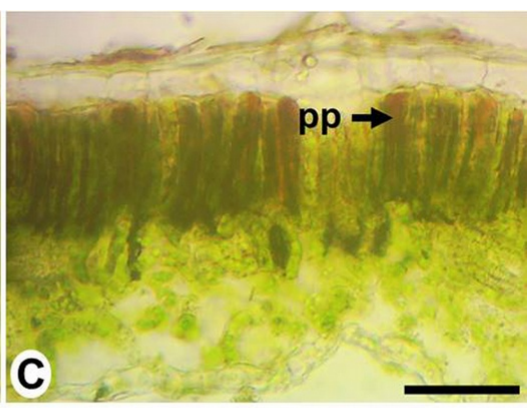

C

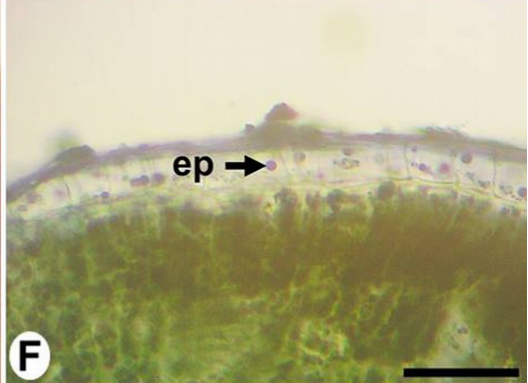

$\mathbf{F}$

id

Figura 3. Histoquímica del limbo de Trema micrantha (L.) Blume. A, B: control; C: dicromato de potasio (10\%) (compuestos fenólicos); D: Dragendorff (alcaloides); E: Sudán III (compuestos lipofílicos); F: Nadi (aceites esenciales); G: floroglucinol (lignina); H, I: ácido clorhídrico (10\%) (naturaleza de los cristales). ct: cutícula; dr: drusa; ep: epidermis; id: idioblasto; pp: parénquima en empalizada; sp: parénquima esponjoso; xy: xilema; las flechas indican una reacción positiva. Barras: $\mathrm{A}=200 \mu \mathrm{m}$; $\mathrm{B}-\mathrm{I}=50 \mu \mathrm{m}$.

Figure 3. Histochemistry of the leaf blade of Trema micrantha (L.) Blume. A, B: control; C: potassium dichromate (10\%) (phenolic compounds); D: Dragendorff (alkaloids); E: Sudan III (lipophilic compounds); F: Nadi (essential oils); G: phloroglucinol (lignin); H, I: hydrochloric acid (10\%) (nature of the crystals). ct: cuticle; dr: druse; ep: epidermis; id: idioblast; pp: palisade parenchyma; sp: spongy parenchyma; xy: xylem; arrows indicate positive reaction. Bars: A $=200 \mu \mathrm{m}$; B-I $=50 \mu \mathrm{m}$.

\begin{tabular}{c|c}
\hline METABOLITES & RESULT \\
\hline Alkaloids & - \\
Monoterpenes and sesquiterpenes & ++ \\
Triterpenes and steroids & ++ \\
Saponins & + \\
Anthraquinones & - \\
Coumarins & - \\
Phenylpropanoglycosides & - \\
Cinnamic derivatives & + \\
Flavonoids & +++ \\
Condensed tannins & - \\
Hydrolyzable tannins & + \\
Reducing sugars & + \\
\hline
\end{tabular}

-: absence of bands; +: up to two bands; ++: two to five bands; +++: above five bands.

Tabla 1. Resultados de la prospección fitoquímica de Trema micrantha (L.) Blume a partir de extractos metanólicos foliares.

Table 1. Results of the phytochemical prospection of Trema micrantha (L.) Blume from leaf methanolic extracts.
Coelho (2008). Nascimento (2017) demonstrated different types of glandular trichomes in species of Cannabaceae and Ulmaceae and stated that these differences support the studies that altered the classification of Celtis and Trema, including them in the Cannabaceae family. The leaf type of T. micrantha differs from that observed in Celtis genus, presenting amphistomatic leaves, as in Celtis iguanaea (Jacq.) Sarg. (Pilati \& Souza 2006).

Adamski \& Coelho (2008) also reported one to two layers of palisade parenchyma cells in the mesophyll of T. micrantha, while Fermino-Junior et al. (2004) found two to three layers of palisade parenchyma in the species. According to Sweitzer, this difference can occur due to environmental adaptations (Sweitzer 1971). This author observed druses and prismatic crystals in the mesophyll of T. micrantha. Calcium oxalate crystals are the 

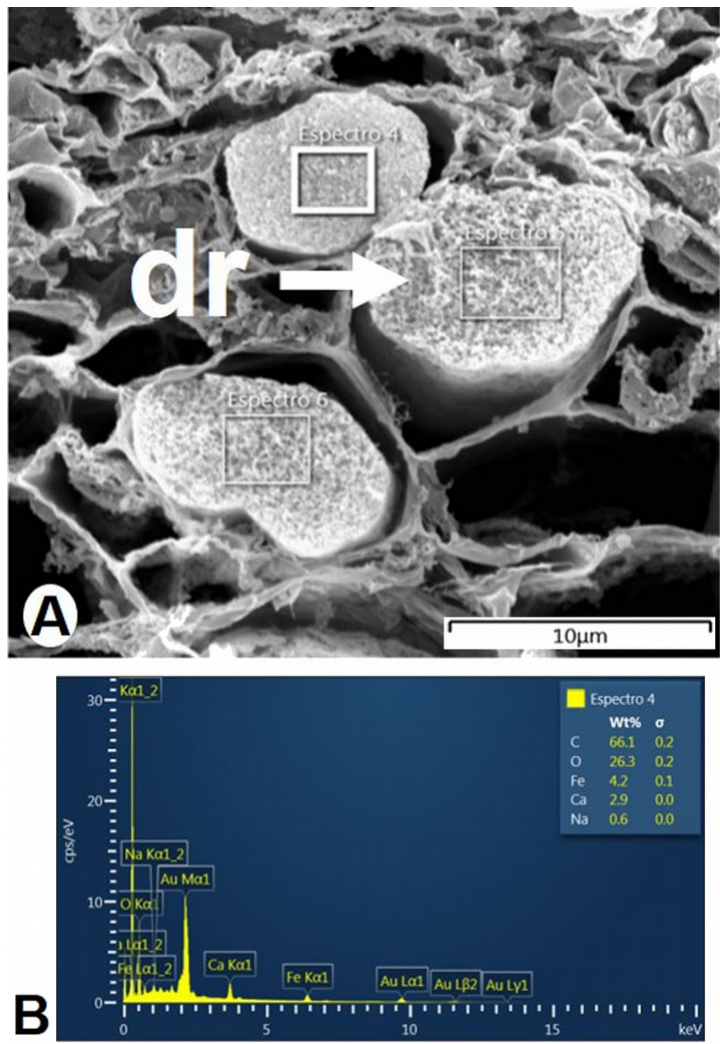

Figura 4. Microscopía electrónica de barrido y composición química elemental de cristales del limbo de Trema micrantha (L.) Blume. A: drusa (dr); B: difractograma.

Figure 4. Scanning electron microscopy and elemental chemical composition of crystals of the leaf blade of Trema micrantha (L.) Blume. A: druse (dr); B: diffractogram.

most common crystals types in plants, whereas calcium carbonate crystals are found in a few families, such as Moraceae, Urticaceae and Acanthaceae (Franceschi \& Horner Junior 1980). Few studies describe the presence of both types of crystals in the same species (Fahn 1990), as verified in the present study for T. micrantha.

There was still no information in the literature on the location of $T$. micrantha metabolites, except for a study focused on the trichomes of the species (Martins \& Pirani 2013). Alkaloids were evidenced in the histochemistry of this study; however, it was not evidenced in the phytochemical characterization. The absence of alkaloids in the methanolic extract of $T$. micrantha can be explained due to the type of extraction, since alkaloids are normally found in acidic fractions.

For this species, the presence of flavonoids in a phytochemical study of the hydromethanolic fraction of leaves has already been mentioned in the literature (Guzzo 2013). Hemayet et al. (2013) have indicated the presence of reducing sugars, tannins, steroids and alkaloids in phytochemical analysis of the crude extract of Trema cannabina Lour. leaves.

Phytosterols, triterpenoids, flavonoids, fixed oil, essential oils, tannins, carbohydrates, saponins, lignin and cardioactive glycosides have been already identified in $T$. orientalis leaf extracts (Patel \& Panchal 2017, Adjileye et al. 2019). Geetha et al. prepared different extracts to identify the compounds of $T$. orientalis. Phytosterols, triterpenoids and fixed oils were identified in the extract with petroleum ether. The methanolic extract showed the presence of tannins and phenolics, flavonoids and carbohydrates. No metabolites were found in the chloroform extract (Geetha et al. 2019).

The researches related to T. micrantha are scarce, even when comparing species of other genera of the Cannabaceae family, showing the importance of the presented study. Microscopic analyses provided important anatomical information, useful for correct identification, since there is variability in the diagnostic characters. Histochemistry and phytochemistry brought unprecedented information about the metabolites present in the species, which expands the information about the genus and the family.

\section{Acknowledgments}

The authors thank Coordenação de Aperfeiçoamento de Pessoal de Nível Superior (CAPES).

\section{References}

Adamski JM \& Coelho GC. 2008. Biomass, Mineral Accumulation, and Calcium Crystals in Trema micrantha (L.) Blume as a Function of Calcium Carbonate Addition. Journal of Plant Nutrition 31 (2): 205-217. https://doi.org/10.1080/01904160701853 $\underline{639}$

Adjileye RAA, Amoussa AMO \& Lagnika L. 2019. Trema orientalis L. and Dialium guineense Wild. used to manage hypertension in Bénin: phytochemical study and antioxidant activity. Journal of Medicinal Plants Studies 7 (3): 43-48.

APG IV. 2016. An update of the Angiosperm Phylogeny Group classification for the orders and families of flowering plants: APG IV. Botanical Journal of Linnean Society 181 (1): 1-20. https://doi.org/10.1111/ boj. 12385

Barbera R, Trovato A, Rapisarda A \& Ragusa S.1992. Analgesic and antiinflammatory activity in acute and chronic conditions of Trema guineense (Schum. et Thonn.) Ficalho and Trema micrantha Blume extracts in rodents. Phytotherapy Research 6 (3): 14648. https://doi.org/10.1002/ptr.2650060309 
Bukatsch F. 1972. Bemerkungen zur doppelfärbung Astrablau-Safranin. Mikrokosmos 61: 255.

David R \& Carde JP. 1964. Coloration différentielle des inclusions lipidique etter peniques des pseudophylles du Pin maritime au moyen du reactif Nadi. Comptes Rendus Hebdomadaires des Séances de I'Academie des Sciences 258: 1338-1340.

Fahn A. 1990. Plant Anatomy. Oxford: Pergamon Press.

Fermino Junior PCP, Paulilo MTS, Reis A \& Santos M. 2004. Espécies pioneiras e climáticas da Floresta Ombrófila Densa: anatomia foliar comparada. Insula 33: 21-37.

Franceschi VR \& Horner Junior HT. 1980. Calcium oxalate crystals in plants. Botanical Review 46 (4): 361427.

Geetha KM, Vishnnupriya K, Jaferi F \& Murugan V. 2019. Preliminary phytochemical investigations and antiepileptic activity of Trema orientalis (linn.) extracts. IJPSR 10 (8): 3957-3962. http://dx.doi.org/10. 13040/IJPSR.0975-8232.10(8).3957-62

Guzzo RN. 2013. Estudo Fitoquímico e Avaliação da Atividade Biológica de Trema micrantha Blume (Cannabaceae). Rio de Janeiro: Universidade Federal do Rio de Janeiro. Masters dissertation.

Haddad A, Sesso A, Attias M, Farina M, Meirelles MN, Silveira M, et al. 1998. Técnicas básicas de microscopia eletrônica aplicadas às Ciências Biológicas. Rio de Janeiro: Sociedade Brasileira de Microscopia Eletrônica.

Harborne JB. 1998. Phytochemical Methods. London: Chapman \& Hall.

Hemayet H, Jahan IA, Islam HS, Kanti DS, Arpona H \& Arif A. 2013. Phytochemical Screening and Antinociceptive Properties of the Ethanolic Leaf Extract of Trema cannabina Lour. Advanced Pharmaceutical Bulletin 3 (1): 103-108. http://dx.doi.org/10.5681/ apb.2013.017

Jensen WA. 1962. Botanical histochemistry, principles and practice. San Francisco: Freeman.

Johansen DA. 1940. Plant microtechnique. New York: McGraw-Hill Book Company Inc.

Kraus JE \& Arduin M. 1997. Manual básico de métodos em morfologia vegetal. Rio de Janeiro: EDUR.

Krauter D. 1985. Erfahrungen mit Etzolds FSA-Färbung für pflanzenschnitte. Mikrokosmos 74: 231-233.

Lorenzi, H. 2000. Plantas daninhas do Brasil: terrestres, aquáticas, parasitas e tóxicas. Nova Odessa, São Paulo: Instituto Plantarum.

Mace ME, Bell AA \& Stipanovic RD. 1974. Histochemistry and isolation of gossypol and related terpenoids in root of cotton seedlings. Phytopathology 64 (10): 1297-1302.

Mace ME \& Howeel CR. 1974. Histochemistry and identification of condensed tannin precursor in roots of cotton seedling. Canadian Journal of Botany 52 (11): 2423-2426. http://dx.doi.org/10.1094/Phyto-64-1297

Machado AFP \& Silva MFO. Cannabaceae in Flora do Brasil 2020 em construção, Jardim Botânico do Rio de Janeiro. Available at http://floradobrasil.jbrj.gov. br/reflora/floradobrasil/FB106887. (accessed on 02VIII-2020)

Martins EGA \& Pirani JR. 2009. Flora da Serra do Cipó,
Minas Gerais: Cannabaceae. Boletim de Botânica 27 (2): 247-251. https://doi.org/10.11606/issn.23169052.v27i2p247-251

Moressi M, Padovan MP \& Pereira ZV. 2014. Seed bank as indicator of restoration in multistrata agroforestry systems in southwestern of Mato Grosso do Sul, Brazil. Revista Árvore 38 (6): 1073-1083. https:// doi.org/10.1590/S0100-67622014000600012

Nascimento IC. 2017. Tricomas secretores em espécies de Cannabaceae e Ulmaceae. Ribeirão Preto, São Paulo: Universidade de São Paulo. Masters dissertation.

Oliveira TJF, Barroso DG, Andrade AG, Freitas ILJ \& Amim RT. 2018. Banco de dementes do solo para uso na recuperação de matas ciliares degradadas na Região Noroeste Fluminense. Ciência Florestal 28 (1): 206-17. http://dx.doi.org/10.5902/198050983 1653

Patel MR \& Panchal HS. 2017. Isolation and Identification of Flavonoid Compounds in Trema orientalis Leaves by Preparative TLC and Various Spectroscopic Techniques. International Journal of Ayurveda and Pharmaceutical Chemistry 6 (1): 238-244.

Pilati R \& Souza LAD. 2006. Morfoanatomia da plântula de morfoanatomia da plântula de Celtis iguanaea (Jacq.) Sarg. (Jacq.) Sarg. (Ulmaceae) (Ulmaceae). Acta Scientiarum. BiologicalSciences 28 (1): 1-6. https://doi.org/10.4025/actascibiolsci.v28i1.1051

Randau KP, Florencio DC, Ferreira CP \& Xavier HS. 2004. Estudo farmacognóstico de Croton rhamnifolius H.B.K. e Croton rhamnifolioides Pax \& amp; Hoffm (Euphorbiaceae). Revista Brasileira de Farmacognosia 14 (2): 89-96. https://doi.org/10.1590/ S0102-695X2004000200001

Sass JE. 1951. Botanical microtechnique. Ames: The lowa State College Press.

Schoenfelder T, Cirimbelli TM \& Citadini-Zanette V. 2006. Acute effect of Trema micrantha (Ulmaceae) on serum glucose levels in normal and diabetic rats. Journal of Ethnopharmacology 107 (3): 456-59. https://doi. org/10.1016/j.jep.2006.07.027

Sweitzer EM. 1971. Comparative anatomy of Ulmaceae. Journal of the Arnold Arboretum 52 (4): 523-585.

Thomas MB. 2001. An analysis of the Pataxó pharmacopoeia of Bahia, Brazil, using an object oriented DATABASE Model. University of Florida In Partial. Masters dissertation.

Viana PL \& Gil ASB. 2018. Flora das cangas da Serra dos Carajás, Pará, Brasil: Cannabaceae. Rodriguésia 69 (1): 49-51. https://doi.org/10.1590/2175$\underline{7860201869105}$

Wagner H \& Bladt S. 2001. Plant Drugs Analisis, a Thin Layer Chromatography. New York: Springer-Verlag Berlin.

Yang MQ, Van Velzen R, Bakker FT, Sattariam A, Li DZ \& Yi TS. 2013. Molecular phylogenetics and character evolution of Cannabaceae. Taxon 62 (3): 473-85.

Yoder LR \& Mahlberg PG. 1976. Reactions of alkaloid and histochemical indicators in laticifers and specialized parenchyma cells of Catharanthus roseus (Apocynaceae). American Journal of Botany 63: 11671173. https://doi.org/10.1002/j.1537-2197.1976.tb13 $\underline{202 . x}$ 